\title{
Variability and Character Association in Indigenous Aromatic Rice (Oryza sativa L.) for Yield and Quality Traits
}

\author{
Rajesh Kumar*, U. K. Singh, Santosh Kumar, N. K. Singh and Avinash Kumar \\ Department of Genetics and Plant Breeding, Dr Rajendra Prasad Agricultural University, \\ Pusa, Samastipur-848125, Bihar, India \\ *Corresponding author
}

\section{A B S T R A C T}

\begin{tabular}{|l|}
\hline Key w o r d s \\
$\begin{array}{l}\text { Variability, heritability, } \\
\text { genetic advance, } \\
\text { correlation, Rice }\end{array}$ \\
\hline Article Info \\
\hline $\begin{array}{l}\text { Accepted: } \\
\text { 28 April } 2018 \\
\text { Available Online: } \\
\text { 10 June } 2018\end{array}$ \\
\hline
\end{tabular}

Sixty rice genotypes were evaluated during kharif 2014 for sixteen quantitative and quality traits to examine the nature and magnitude of variability, heritability, genetic advance and correlation. Analysis of variance revealed that the differences among sixty genotypes were significant for all the characters. The characters viz., number of effective tillers per plant, seeds per panicle and brown rice length exhibited high Genotypic Coefficient of Variation (GCV) and Phenotypic Coefficient of Variation (PCV). Small differences between GCV and PCV were recorded for all the characters studied which indicated less influence of environment on these characters. The characters viz., 100 seed weight, seeds per panicle, brown rice length and kernel length exhibited high heritability coupled with high genetic advance indicating that simple selection could be effective for improving these characters. Grain yield per plant had significant and positive correlation with days to $50 \%$ flowering, days to maturity, plant height, effective tillers per plant, panicle length, seeds per panicle and kernel breadth after cooking.

\section{Introduction}

Rice (Oryza sativa L.) is a staple food crop for more than $40 \%$ of the world population. Millions of people depend on it, as a source of food and income. Thus, it requires a continuous improvement in productivity, besides profitability in rice farming system on sustainable basis.

Apart from yield, food consumption pattern in the recent years has encouraged the attention towards grain quality. Aromatic rice has a special place in world rice market. There is an increasing demand for the production of high grain quality aromatic rice in India due to its export earnings and rising standard of living. India has an immense wealth of aromatic short grain rice. But a lot has been already lost as an aftermath of the green revolution where major emphasis was on yield rather than quality (Singh and Singh, 1998).

This is despite the fact that some of the nonbasmati scented rice is much superior to basmati types with respect to traits like aroma, kernel elongation after cooking, fluffiness, taste, etc. Nevertheless, due to the special attachment of the farmers with Basmati rice, a large number of them are still in existence. 
The cultivation of small and medium grain non-basmati scented rice have adapted to specific localities and conditions, but are widely distributed in different parts of the country. All the traditional varieties are tall, photosensitive, with average to very strong aroma, and up to 100 to 200 per cent of kernel elongation after cooking, but have long duration and low yields. Therefore, there is urgent need to improve the yield potential of such rice. The present investigation was carried out with the objectives of estimating the genetic variability in aromatic short grain rice for yield, yield attributing characters and quality traits.

\section{Materials and Methods}

The present experiment was conducted with 60 genotypes collected from different regions (table-3) during kharif 2014 at Agriculture Research Farm, Dr Rajendra Prasad Agricultural University (Formerly Rajendra Agricultural University) in randomized complete block design. Each entry was sown in five row plots of $5 \mathrm{~m}$ length with $20 \mathrm{~cm}$ inter row space with three replications. Five plants from each replication were selected at random and observations were recorded on 16 characters viz., days to $50 \%$ flowering, days to maturity, plant height $(\mathrm{cm})$, effective tillers per plant, panicle length $(\mathrm{cm})$, seeds per panicle, seed weight $(\mathrm{g})$, brown rice length $(\mathrm{mm})$, brown rice width $(\mathrm{mm})$, kernel length $(\mathrm{mm})$, kernel breadth(mm), kernel length after cooking $(\mathrm{mm})$, kernel breadth after cooking $(\mathrm{mm})$, alkali spread value, ACamylose content, yield per plant $(\mathrm{g})$. Days to 50 percent flowering and Days to maturity was computed on plot basis. The mean over replication of each character was subjected to statistical analysis. The phenotypic, genotypic coefficient of variability (PCV, GCV), heritability in broad sense and expected genetic advance at 5 percent selection intensity were computed by using formulae suggested by Johnson et.al (1955). The phenotypic and genotypic correlations were calculated following the method of Singh and Choudhary (1985).

\section{Results and Discussion}

Greater variability in the initial breeding material ensures better chances of producing desired forms of a crop plant. Thus, the primary objective of germplasm conservation is to collect and preserve the genetic variability in indigenous collection of crop species to make it available to present and future generations. The analysis of variance indicated the existence of significant differences among all the genotypes for all the traits studied. Analysis of variance revealed significant differences within the genotypes for all the traits studied. The characters studied in the present investigation exhibited low, moderate and high PCV and GCV values. Among the yield characters, highest PCV and GCV values were recorded for effective tillers per plant, followed by seeds per panicle and the lowest PCV and GCV values were recorded for panicle length. Among the grain quality characters highest PCV and GCV values were recorded for brown rice length, followed by kernel length and the lowest values were recorded for amylose content (Table-1). Similar findings were also reported by Rita et al., (2009) and Gangashetty et al., (2013). Coefficients of variation studies indicated that the estimates of PCV were slightly higher than the corresponding GCV estimates for all the traits studied indicating that the characters were less influenced by the environment. Therefore, selection on the basis of phenotype alone can be effective for the improvement of these traits.

The estimates of heritability act as predictive instrument in expressing the reliability of phenotypic value. Therefore, high heritability helps in effective selection for a particular 
character. The characters studied in the present investigation expressed low to high heritability estimates ranging from 53 to 99 percent. Among the yield characters, highest heritability was recorded for days to maturity followed by days to flowering, plant height and 100 seed weight, whereas, all grain quality characters exhibited high heritability. Similar findings were also reported by Karthikeyan et al., (2010) and Anandrao et al., (2011). High heritability values indicate that the characters under study are less influenced by environment in their expression. High heritability indicates the scope of genetic improvement of these characters through selection.

The genetic advance is a useful indicator of the progress that can be expected as a result of exercising selection on the pertinent population. Heritability in conjunction with genetic advance gives a more reliable index of selection value (Johnson et al., 1955). Genetic advance was highest for plant height followed by days to $50 \%$ flowering and days to maturity and lowest for 100 seed weight among yield characters whereas all grain quality characters exhibited low genetic advance. The genetic advance as per cent of mean was highest for seeds per panicle followed by 100 seed weight and effective tillers per plant while moderate value recorded by panicle length among yield characters, whereas, for grain quality characters, brown rice length showed highest genetic advance as percent of mean, while moderate value was recorded for amylose content (Table-1). Similar findings were also reported by Patil et al., (2003) and Gangashetty et al., (2013). The information on genetic variation, heritability and genetic advance helps to predict the genetic gain that could be obtained in later generations, if selection is made for improving the particular trait under study.

Table.1 Estimation of Genetic parameters for different quantitative \& qualitative characters in indigenous short grain rice

\begin{tabular}{|l|l|l|l|l|l|l|}
\hline S.NO & Character & PCV & GCV & $h^{2}(\mathbf{b s}) \%$ & GA & GA as \% of mean \\
\hline $\mathbf{1}$ & DTF & 14.35 & 14.33 & 98 & 36.03 & 29.47 \\
\hline $\mathbf{2}$ & DTM & 11.27 & 11.24 & 99 & 34.95 & 23.09 \\
\hline $\mathbf{3}$ & PH & 17.52 & 17.30 & 98 & 53.68 & 35.21 \\
\hline $\mathbf{4}$ & ETP & 33.16 & 24.17 & 53 & 3.21 & 36.30 \\
\hline $\mathbf{5}$ & PL & 12.10 & 10.16 & 71 & 4.69 & 17.58 \\
\hline $\mathbf{6}$ & SP & 32.15 & 30.65 & 91 & 26.88 & 60.18 \\
\hline $\mathbf{7}$ & 100SW & 27.95 & 27.66 & 98 & 0.95 & 56.36 \\
\hline $\mathbf{8}$ & BRL & 23.73 & 23.62 & 94 & 2.61 & 48.43 \\
\hline $\mathbf{9}$ & BRW & 12.55 & 12.28 & 96 & 0.49 & 24.77 \\
\hline $\mathbf{1 0}$ & KL & 23.40 & 23.30 & 99 & 2.54 & 47.79 \\
\hline $\mathbf{1 1}$ & KB & 13.52 & 13.02 & 93 & 0.49 & 25.85 \\
\hline $\mathbf{1 2}$ & KLAC & 20.63 & 20.53 & 96 & 3.85 & 42.07 \\
\hline $\mathbf{1 3}$ & KBAC & 17.29 & 16.72 & 94 & 0.90 & 33.31 \\
\hline $\mathbf{1 4}$ & ASV & 20.53 & 18.42 & 81 & 1.54 & 34.05 \\
\hline $\mathbf{1 5}$ & AC & 7.52 & 7.46 & 98 & 3.51 & 15.25 \\
\hline $\mathbf{1 6}$ & Y/P & 38.60 & 28.17 & 53 & 8.67 & 42.36 \\
\hline
\end{tabular}

DTF-days to 50\% flowering, DTM-days to maturity, PH- plant height, ETP-effective tillers per plant, PL-panicle length, SP- seeds per panicle, 100SW- seed weight, BRL-brown rice length, BRW- brown rice width, KL-kernel length, KB-kernel breadth, KLAC-kernel length after cooking, KBAC-kernel breadth after cooking, ASV-alkali spread value, AC- amylose content, Y/P-yield per plant. 
Table.2 Estimation of genotypic and phenotypic correlation coefficient for different quantitative \& qualitative characters in indigenous short grain rice

\begin{tabular}{|c|c|c|c|c|c|c|c|c|c|c|c|c|c|c|c|c|}
\hline $\begin{array}{l}\text { Characte } \\
\mathbf{r}\end{array}$ & & DTM & PH & ETP & PL & SP & $100 S W$ & BRL & BRW & KL & KB & KLAC & KBAC & ASV & $\mathrm{AC}$ & $\mathbf{Y} / \mathbf{P}$ \\
\hline \multirow[t]{2}{*}{ DTF } & G & $0.9880 * *$ & $0.7764 * *$ & $0.2700 * *$ & 0.0999 & $0.6044 * *$ & $-0.6291 * *$ & $-0.7559 * *$ & $0.4040 * *$ & $-0.7508 * *$ & $0.5010 * *$ & $-0.4152 * *$ & $0.3460 * *$ & $0.1885^{*}$ & -0.0514 & $0.4218 * *$ \\
\hline & $\mathrm{P}$ & $0.9863 * *$ & $0.7663 * *$ & $0.1913 *$ & 0.0835 & $0.5770 * *$ & $-0.6205^{* *}$ & $-0.7511 * *$ & $0.3956^{* *}$ & $-0.7462 * *$ & $0.4832 * *$ & $-0.4124 * *$ & $0.3336^{* *}$ & $0.1669 *$ & -0.0513 & $0.3093 * *$ \\
\hline \multirow[t]{2}{*}{ DTM } & G & 1.0000 & $0.8077 * *$ & $0.2702 * *$ & $0.1730 *$ & $0.6056 * *$ & $-0.5661 * *$ & $-0.7069 * *$ & $0.4526^{* *}$ & $-0.7003 * *$ & $0.5433 * *$ & $-0.3295 * *$ & $0.4073 * *$ & $0.1705^{*}$ & -0.0803 & $0.4332 * *$ \\
\hline & $\mathrm{P}$ & & $0.7963 * *$ & $0.1942 * *$ & $0.1507 *$ & $0.5767 * *$ & $-0.5567 * *$ & $-0.7011 * *$ & $0.4430 * *$ & $-0.6958 * *$ & $0.5226 * *$ & $-0.3273 * *$ & $0.3921 * *$ & $0.1497 *$ & -0.0807 & $0.3188 * *$ \\
\hline \multirow[t]{2}{*}{ PH } & G & & 1.0000 & 0.0833 & $0.3734 * *$ & $0.5104 * *$ & $-0.3197 * *$ & $-0.5080 * *$ & $0.4752 * *$ & $-0.5149 * *$ & $0.5853 * *$ & -0.0351 & $0.4443 * *$ & 0.0091 & $-0.2100 * *$ & $0.3721 * *$ \\
\hline & $\mathrm{P}$ & & 1.0000 & 0.0556 & $0.3164 * *$ & $0.4726^{* *}$ & $-0.3111 * *$ & $-0.5015^{* *}$ & $0.4613^{* *}$ & $-0.5070 * *$ & $0.5548 * *$ & -0.0347 & $0.4240 * *$ & 0.0061 & $-0.2046^{* *}$ & $0.2661 * *$ \\
\hline \multirow[t]{2}{*}{ ETP } & G & & & 1.0000 & -0.0941 & -0.0670 & $-0.3365 * *$ & $-0.2146^{* *}$ & -0.1286 & $-0.1764 *$ & -0.1342 & $-0.2277 * *$ & $0.1700 *$ & 0.0392 & -0.1057 & $0.6463 * *$ \\
\hline & $\mathrm{P}$ & & & 1.0000 & 0.0031 & 0.0058 & $-0.2463 * *$ & -0.1435 & -0.0904 & -0.1181 & -0.0915 & $-0.1651^{*}$ & 0.1096 & 0.0195 & -0.0724 & $0.4742 * *$ \\
\hline \multirow[t]{2}{*}{ PL } & G & & & & 1.0000 & $0.3171 * *$ & 0.0721 & -0.0458 & $0.3440 * *$ & -0.0185 & $0.3876^{* *}$ & $0.3157 * *$ & $0.2672 * *$ & 0.1104 & $-0.3303 * *$ & $0.3075 * *$ \\
\hline & $\mathrm{P}$ & & & & 1.0000 & $0.2588 * *$ & 0.0715 & -0.0320 & $0.2638 * *$ & -0.0231 & $0.3087 * *$ & $0.2555^{* *}$ & $0.2183 * *$ & 0.0917 & $-0.2716^{* *}$ & $0.2046^{* *}$ \\
\hline \multirow[t]{2}{*}{ SP } & G & & & & & 1.0000 & $-0.4961 * *$ & $-0.5171 * *$ & $0.2444 * *$ & $-0.5162 * *$ & $0.3441 * *$ & $-0.2721 * *$ & $0.2549 * *$ & 0.0243 & 0.0772 & $0.5548 * *$ \\
\hline & $\mathrm{P}$ & & & & & 1.0000 & $-0.4615 * *$ & $-0.4936 * *$ & $0.2358 * *$ & $-0.4863 * *$ & $0.3162 * *$ & $-0.2525^{* *}$ & $0.2338 * *$ & 0.0457 & 0.0739 & $0.3892 * *$ \\
\hline \multirow[t]{2}{*}{$100 \mathrm{SW}$} & G & & & & & & 1.0000 & $0.8340 * *$ & -0.0253 & $0.8381 * *$ & -0.1054 & $0.7148 * *$ & -0.0923 & -0.0968 & -0.1253 & $-0.2723 * *$ \\
\hline & $\mathrm{P}$ & & & & & & 1.0000 & $0.8229 * *$ & -0.0234 & $0.8256^{* *}$ & -0.0964 & $0.7033 * *$ & -0.0929 & -0.0835 & -0.1230 & $-0.1932 * *$ \\
\hline \multirow[t]{2}{*}{ BRL } & G & & & & & & & 1.0000 & $-0.3968 * *$ & $0.9811 * *$ & $-0.5319 * *$ & $0.7072 * *$ & $-0.2982 * *$ & -0.1396 & -0.1172 & $-0.2339 * *$ \\
\hline & $\mathrm{P}$ & & & & & & & 1.0000 & $-0.3869 * *$ & $0.9738 * *$ & $-0.5107 * *$ & $0.6987 * *$ & $-0.2892 * *$ & -0.1265 & -0.1155 & $-0.1612 *$ \\
\hline \multirow[t]{2}{*}{ BRW } & G & & & & & & & & 1.0000 & $-0.4320 * *$ & $0.8522 * *$ & -0.0563 & $0.5704 * *$ & 0.0198 & -0.1318 & 0.1248 \\
\hline & $\mathrm{P}$ & & & & & & & & 1.0000 & $-0.4209 * *$ & $0.8168 * *$ & -0.0505 & $0.5374 * *$ & 0.0398 & -0.1274 & 0.0624 \\
\hline \multirow[t]{2}{*}{ KL } & G & & & & & & & & & 1.0000 & $-0.5279 * *$ & $0.7210 * *$ & $-0.3284 * *$ & -0.1144 & -0.1151 & $-0.2236 * *$ \\
\hline & $\mathrm{P}$ & & & & & & & & & 1.0000 & $-0.5004 * *$ & $0.7170 * *$ & $-0.3159 * *$ & -0.0956 & -0.1144 & $-0.1686^{*}$ \\
\hline \multirow[t]{2}{*}{ KB } & G & & & & & & & & & & 1.0000 & -0.0900 & $0.5718^{* *}$ & -0.0074 & -0.0836 & $0.2194 * *$ \\
\hline & $\mathrm{P}$ & & & & & & & & & & 1.0000 & -0.0839 & $0.5404 * *$ & 0.0058 & -0.0825 & 0.1394 \\
\hline \multirow[t]{2}{*}{ KLAC } & G & & & & & & & & & & & 1.0000 & 0.0165 & 0.0500 & $-0.1720 *$ & -0.0591 \\
\hline & $\mathrm{P}$ & & & & & & & & & & & 1.0000 & 0.0250 & 0.0596 & $-0.1718^{*}$ & -0.0644 \\
\hline \multirow[t]{2}{*}{ KBAC } & G & & & & & & & & & & & & 1.0000 & 0.0234 & $-0.2348 * *$ & $0.4080 * *$ \\
\hline & $\mathrm{P}$ & & & & & & & & & & & & 1.0000 & 0.0515 & $-0.2275^{* *}$ & $0.2320 * *$ \\
\hline \multirow[t]{2}{*}{ ASV } & G & & & & & & & & & & & & & 1.0000 & 0.0543 & -0.0323 \\
\hline & $\mathrm{P}$ & & & & & & & & & & & & & 1.0000 & 0.0493 & -0.0987 \\
\hline \multirow[t]{2}{*}{$\mathrm{AC}$} & G & & & & & & & & & & & & & & 1.0000 & -0.1276 \\
\hline & $\mathrm{P}$ & & & & & & & & & & & & & & 1.0000 & -0.0881 \\
\hline
\end{tabular}

* \&** represents significant levels at $5 \%$ and $1 \%$ respectively.

DTF-days to 50\% flowering, DTM-days to maturity, PH- plant height, ETP-effective tillers per plant, PL-panicle length, SP- seeds per panicle, 100SW- seed weight, BRL-brown rice length, BRW- brown rice width, KL-kernel length, KB-kernel breadth, KLAC-kernel length after cooking, KBAC-kernel breadth after cooking, ASV- alkali spread value, AC- amylose content, Y/P-yield per plant. 
Table.3 Details of sixty rice genotypes

\begin{tabular}{|c|c|c|}
\hline Genotypes & No. of Accessions & Origin \\
\hline Adam chini & 7 & Uttar Pradesh \\
\hline Jeerabattis & 1 & Uttar Pradesh \\
\hline Thurunbhog & 1 & Orissa \\
\hline Dhanaprasad & 1 & Orissa \\
\hline Chinnor & 1 & Madhya Pradesh \\
\hline Jaiphula & 1 & Orissa \\
\hline Dubraj & 1 & Chhattisgarh \\
\hline Shakkarchini & 1 & Uttar Pradesh \\
\hline Ketkijoha & 1 & Assam \\
\hline Lalchandan & 1 & Madhya Pradesh \\
\hline Jeerigasambha & 1 & Tamil Nadu \\
\hline Jawaphool & 1 & Madhya Pradesh \\
\hline Indrabhog & 1 & Uttar Pradesh \\
\hline Lanjhi & 1 & Madhya Pradesh \\
\hline Tulsimanjari & 1 & Bihar \\
\hline Lalmati & 1 & Uttar Pradesh \\
\hline Basmati local & 6 & Uttar Pradesh \\
\hline Kala namak & 11 & Uttar Pradesh \\
\hline Juhibengal & 3 & West Bengal \\
\hline Kanakjeera & 7 & Uttar Pradesh \\
\hline Ram bhog & 1 & Uttar Pradesh \\
\hline Dhania & 1 & Uttar Pradesh \\
\hline Hariram & 1 & Uttar Pradesh \\
\hline Shyamjeera & 1 & Uttar Pradesh \\
\hline Govindbhog & 1 & Orissa \\
\hline Krishna hamsa & 1 & Andhra Pradesh \\
\hline Badshahbhog & 5 & Assam \\
\hline
\end{tabular}

The genotypic correlations in general were higher than the corresponding phenotypic correlations. This is due to the effect of environment on character association at the tillers per plant, seeds per panicle, days to maturity, days to 50 per cent flowering, kernel breadth after cooking, panicle length and kernel breadth at both genotypic and phenotypic levels indicating the importance of these characters for yield improvement.

The correlation analysis revealed that there is significant and positive association of grain yield with days to $50 \%$ flowering, days to maturity, plant height, effective tillers per plant, panicle length, seeds per panicle and kernel breadth after cooking at both phenotypic and genotypic level. When characters having direct bearing on yield are selected, their associations with other characters are to be considered simultaneously as this will indirectly affect yield. Significant positive correlations at both the levels were recorded for days to 50 percent flowering with days to maturity, plant height, effective tillers per plant, seeds per 
panicle, brown rice width, kernel breadth, kernel breadth after cooking and alkali spread value (Table-2). The observed positive correlation of grain yield with various traits was supported by earlier workers viz., Rao and Srivastava (1999), Rajeshwari and Nandarajan (2004) and Ekka et al., (2011) for days to 50\% flowering; Chaturvedi et al., (2008), Reddy et al., (2008), Ekka et al., (2011) and Rangare et al., (2012) for plant height; Ekka et al., (2011) for panicle length; Hari et al., (2006), Nandan et al., (2010) and Rangare et al., (2012) for spikelets per panicle.

Significant negative correlations were noted for 100 seed weight with days to 50 percent flowering, days to maturity, plant height, effective tillers per plant and seeds per panicle (Table-2). Pleiotropy or linkage may also be the genetic reasons for this type of negative association. When two characters show negative phenotypic and genotypic correlation it would be difficult to exercise simultaneous selection for these characters in the development of a variety. Hence, under such situations, judicious selection programme might be formulated for simultaneous improvement of such important component characters.

The results of correlation coefficients implied that effective tillers per plant, seeds per panicle days to maturity and days to 50 percent flowering may be considered for selection for yield improvement.

\section{References}

Anandrao SD, Singh CM, Suresh BG and Lavanya GR (2011). Evaluation of rice hybrids for yield and yield component characters under North East Plain Zone. The Allahabad Farmer., 67(1): 63-68.

Chauturvedi S, Lal P, Pandey MP, Verma S and Singh A P (2008). Component analysis for grain yield in hybrid rice under tarai condition. Oryza 45: 1-6.

Gangashetty PI, Salimath PM and Hanamaratti NG (2013). Genetic variability studies in genetically diverse non-basmati local aromatic genotypes of rice (Oryza sativa L.). Rice Genomics \& Genet. 4(2): 4-8.

Hari Rama Krishnan S, Ananda Kumar CR, Saravanan S and Malini M (2006). Association analysis of some yield traits in rice. J. of applied Sci. Res., 2(7): 402404.

Johnson HN, Robinson HF and Comstock RE (1955). Estimates of genetic and environmental variability in soybean. Agron J. 27: 314-318.

Karthikeyan P, Anbuselvan Y, Elangaimannan $\mathrm{R}$ and Venkatesan $\mathrm{M}$ (2010). Variability and heritability studies in rice (Oryza sativa L.) under coastal salinity. Elec. J. Pl. Breed., 1 (2): 196-198.

Nandan R, Sweta and Singh SK (2010). Character association and path analysis in rice genotypes. World J. of Agri. Sci. 6(2): 201-206.

Patil PV, Sarawgi AK and Shrivastava MN (2003). Genetic analysis of yield and quality traits in traditional aromatic accessions of rice. J. Maharashtra Agric. Univ., 28(3): 225-258.

Rajeshwari S and Nandarajan N (2004). Correlation between yield and yield components in rice (Oryza sativa L.). Agric. Sci. Dig., 24: 280-282.

Rangare NR, Krupakar A, Ravichandra K, Shukla AK and Mishra AK (2012). Estimation of characters association and direct and indirect effects of yield contributing traits on grain yield in exotic and Indian rice (Oryza sativa L.) germplasm. International J. of Agri. Sci. 2(1): 54-61. 
Rao SS and Shrivastava MN (1999). Association among yield attributes in upland rice. Oryza 36: 13-15.

Reddy MY, Yadav SC, Suresh Reddy B, Lavanya GR and Suresh Babu G (2008). Character association and component analysis in rice. Oryza 45: 239-241.

Rita Bisne, Sarawgi AK and Verulkar SB (2009). Study of heritability, genetic advance and variability for yield contributing characters in rice. Bangladesh J. Agril. Res. 34(2) - 175179.

Ruth Elizabeth Ekka, Sarawgi AK and Raja Kanwar R (2011). Correlation and path analysis in traditional rice accessions of Chhattisgarh. J. of Rice Res. 4(1\&2): 1118.

Singh RK and Choudhary BD (1985). Biometrical methods in quantitative genetic analysis. Kalyani Publ., New Delhi, India.57-78 pp.

Singh RK and Singh US (1998). Indigenous scented rices of India: a survival issue. In: Sustainable Agriculture for Food, Energy and Industry (N. E. Bassam, R. K. Behl and B. Prohnow, eds.). Proc. Int'l conference held in braunschweig (Germany). pp. 676-681.

\section{How to cite this article:}

Rajesh Kumar, U. K. Singh, Santosh Kumar, N. K. Singh and Avinash Kumar. 2018. Variability and Character Association in Indigenous Aromatic Rice (Oryza sativa L.) for Yield and Quality Traits. Int.J.Curr.Microbiol.App.Sci. 7(06): 3722-3728.

doi: https://doi.org/10.20546/ijcmas.2018.706.436 